\title{
Correction to: Digital girl: cyberfeminism and the emancipatory potential of digital entrepreneurship in emerging economies
}

\author{
Maura McAdam • Caren Crowley • Richard T. Harrison
}

Published online: 19 February 2020

(C) Springer Science+Business Media, LLC, part of Springer Nature 2020

\section{Correction to: Small Bus Econ}

https://doi.org/10.1007/s11187-019-00301-2

The original version of this article unfortunately contained a mistake. The co-author's name Caren Crowley and Richard T. Harrison were missing in the published paper.

The corrected authorgroup is shown above and the corresponding affiliations are shown below.

Publisher's note Springer Nature remains neutral with regard to jurisdictional claims in published maps and institutional affiliations.

M. McAdam $(\bowtie)$

DCU Business School, Dublin City University, Glasnevin, Dublin 9, Ireland

e-mail: maura.mcadam@dcu.ie

C. Crowley

Maastricht School of Management, Endepolsdomein 150,

Maastricht 6229 EP, The Netherlands

R. T. Harrison

University of Edinburgh Business School, 29 Buccleuch Place,

Edinburgh EH89JS, UK 